\author{
Maria Matusiewicz \\ Dr nauk ekonomicznych \\ Uniwersytet Gdański, Wydział \\ Ekonomiczny, Katedra Polityki \\ Transportowej \\ m.matusiewicz@ug.edu.pl
}

DOI: 10.35117/A_ENG_19_12_01

\title{
Developing a sustainable urban transport policy in the \& eld of supply in the face of the latest challenges
}

\begin{abstract}
Transport of urban goods has a signifi cant impact on the lives of residents and the functioning of the local economy. At the same time, it creates numerous problems related to the impact on the environment and the surroundings. Thus, the distribution of goods in the city has a signifi cant impact on the lives of residents and tourists' impressions. Due to the fact that 25 percent EU emissions from transport come from urban areas, cities play a key role in mitigating the negative eff ects of transport. Many cities are currently implementing Sustainable Urban Mobility Plan (SUMP) that focus on people's mobility. In most cases, the distribution of goods is not mentioned in the SUMP or is mentioned briefl y. In the absence of clear guidelines for resolving urban transport issues, some cities have adopted various strategic documents and measures. In the absence of standardization of documents, it is diffi cult to compare them and determine the level of city advancement in the implementation of urban logistics measures. To overcome this problem, the EC initiated the concept of Sustainable Urban Logistics Plan (SULP). The article presents the structure and plan of implementing SULP.
\end{abstract}

Keywords: Sustainable urban logistics plan; SULP; City logistics; urban freight transport

Urban transport occupies an increasingly important place in the strategic design of urban mobility and in spatial planning.

Although the transport of urban goods is crucial for the functioning of each of us and for the local economy, it generates numerous problems by increasing pollution emissions, noise, crowded roads, increased stress of residents and drivers, as well as increased aggression of the latter. Thus, the distribution of goods in the city has a significant impact on the lives of residents and the tourists' impressions.

Considering the percentage of total commercial vehicle traffic (18\%), the flow of goods disproportionately reduces the quality of life in the city ( $40 \%$ of transport emissions). What's more, existing problems are perpetual motion devices - they exacerbate them, because the efficiency of distribution of goods and travel of residents in cities is reduced by congestion [4]. 

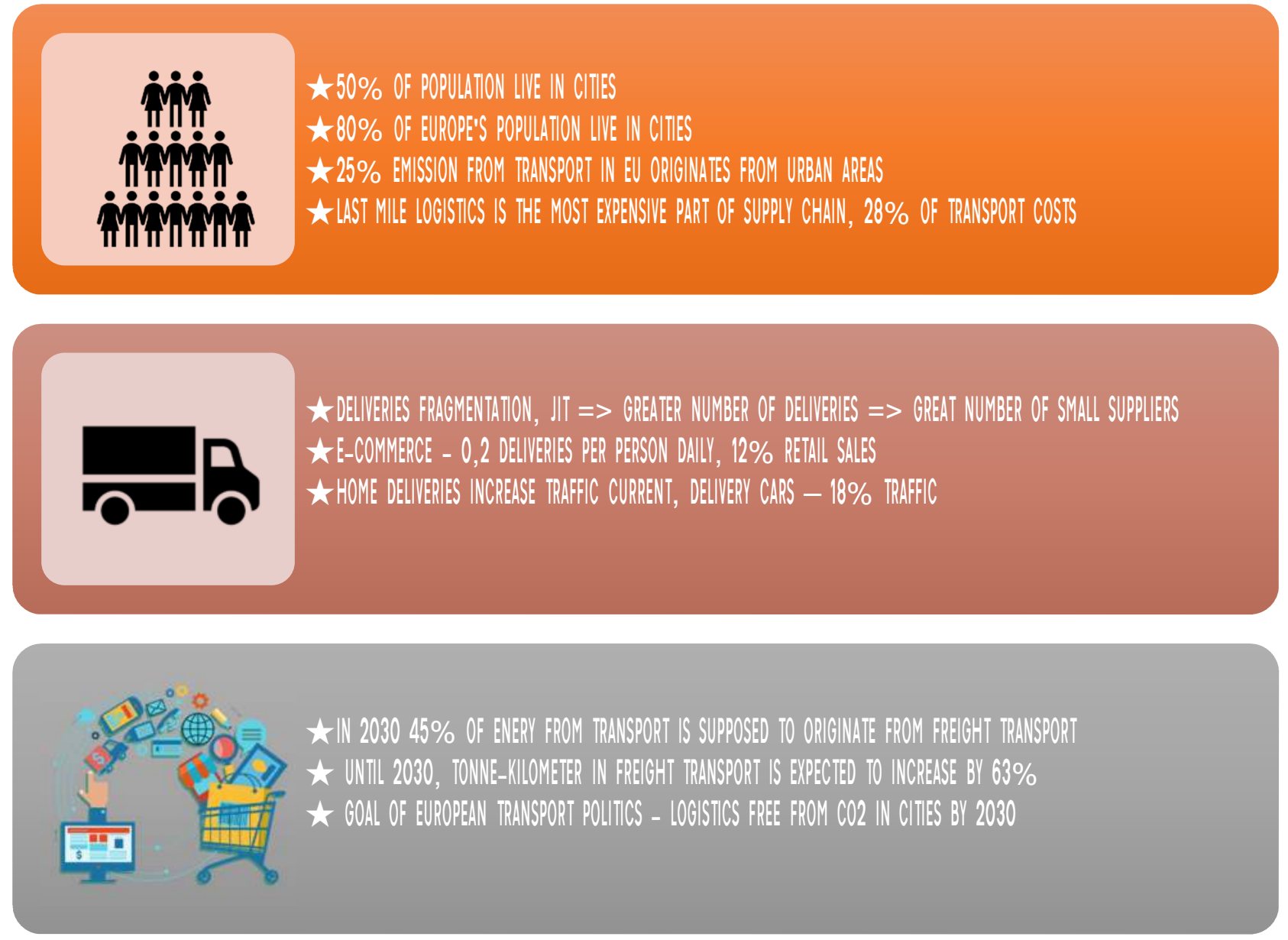

1. Chosen facts about city logistics

Source: Personal research from [4].

Furthermore, in view of the higher risk of disasters caused by global climate change and aging societies, urban freight transport should take into account the risks to creating more sustainable and livable cities.

Environmental problems and accessibility to cities related to passenger transport or distribution of urban goods threaten the profitability and sustainability of urban areas. Effective distribution of goods has become the criterion for assessing sustainable development strategies between cities.

There is therefore a strong trend among citizens and among many stakeholders to look for new ways of transporting goods in urban areas.

Stakeholders in the city represent four groups (Fig. 1):

$\star$ SUPPLIERS (suppliers, wholesalers)

$\star$ CARRIERS (carriers, storage companies)

$\star$ RESIDENTS (consumers)

$\star$ ADMINISTRATION (country, regional and local level). 


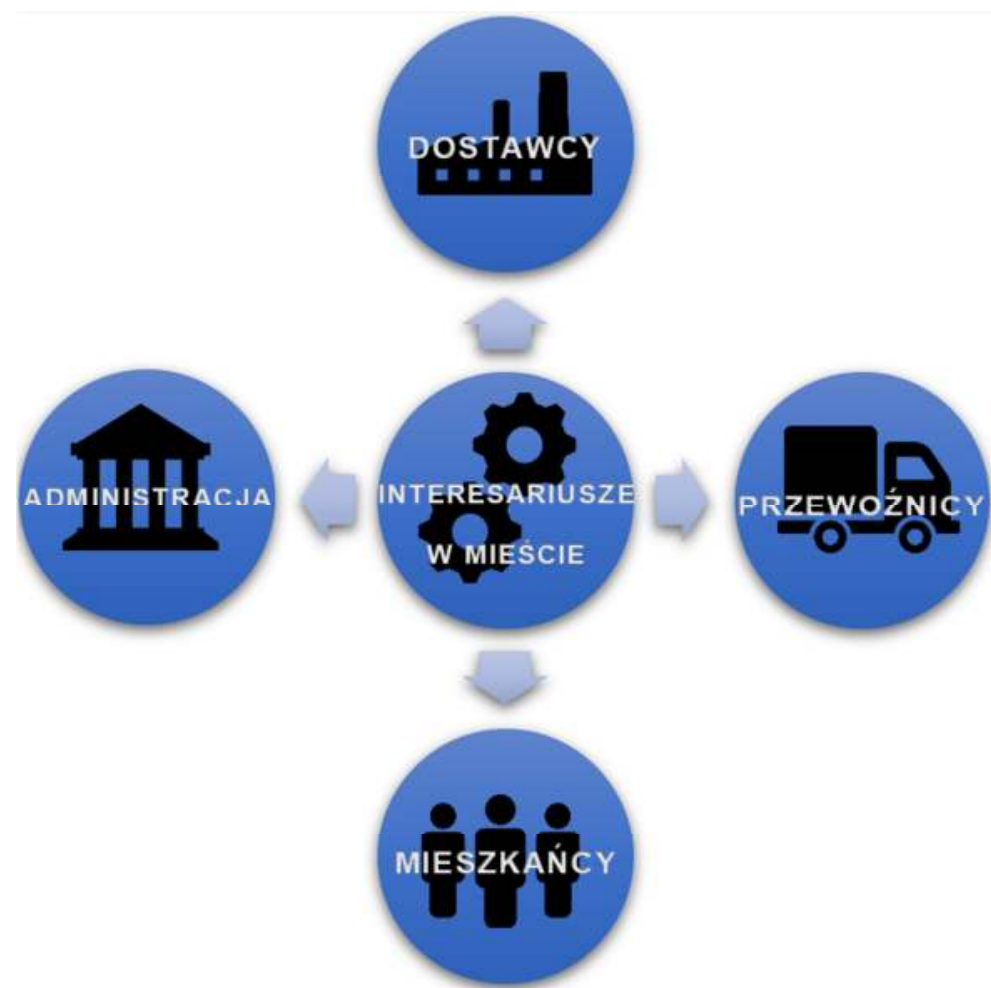

Fig. .2. Stakeholders in the city

Source: Personal research

All these stakeholders do not have the same viewpoints, and the goals of each group can create a conflict of interest. Achieving a compromise is key to implementing effective urban logistics solutions.

A compromise can be achieved thanks to the Freight Quality Partnership (FQP). This partnership should be seen as a key factor in the analysis and implementation of effective logistics initiatives in the city. Their acceptance can be a key factor in the success of the city's transport policy.

A number of urban logistics policies have been implemented in cities around the world. Modeling techniques have also been developed for planning and assessing urban logistics policy measures. This article presents the conditions necessary to create a Sustainable Urban Logistics Plan.

Urban logistics can contribute to the creation of more efficient and environmentally friendly urban freight transport systems, through [4]:

* the use of innovative ICT (information and communication technologies) and ITS (intelligent transport systems),

change in the thinking of logistics managers,

public-private partnership

The use of innovative ICT and ITS technologies in urban freight transport allows for the collection of accurate data on freight transport in the city. Digital data can be used to optimize delivery routes and planning in a dynamic way depending on changing conditions. This type of optimization can help reduce logistics costs, reduce CO2, NOx and SPM emissions, as well as reduce traffic [4].

A change in the thinking of logistics managers is crucial for urban logistics, because logistics managers are key players in urban freight transport operations. A number of transport and logistics companies have obtained ISO9001 (Quality Management) and ISO14001 (Environmental Management) certification. This certification provides logistics 
companies with the opportunity to educate employees about actions to develop greener logistics systems, such as eco-driving trucks, resulting in reduced fuel costs and breakdowns through a smoother way of driving. The green image of companies can help them get a good reputation in the market [4].

The third indispensable element of urban logistics is public-private partnership. In traditional transport planning, administrators mainly develop transport plans based on their own surveys and data. Public-private partnerships enable all interested parties to participate in the development of urban transport plans for goods from an early stage. Sharing data between private companies and the public sector is necessary to understand the situation of goods distribution and related problems.

During the discussion, administrators can learn about the other stakeholders' attitude on planned urban logistics policy measures. This procedure avoids unexpected side effects and deployment failures. PPP can be implemented through the Freight Quality Partnership (FQP).

\section{Urban transport policy and measures implemented in strategic documents of European cities}

European transport policy aims to support the decarbonisation of transport by gradually implementing various measures to achieve desired goals by 2050 , including CO2-free urban logistics, no conventionally driven vehicles in cities or no fatalities in cities.

Due to the fact that 25 percent EU emissions from transport come from urban areas, cities play a key role in mitigating the negative effects of transport.

Many cities are currently implementing Sustainable Urban Mobility Plan (SUMP) that focus on people's mobility. In most cases, the distribution of goods is not mentioned in the SUMP or is mentioned briefly.

In the absence of clear guidelines for resolving urban transport issues, some cities have adopted various strategic documents and measures. In the absence of standardization of documents, it is difficult to compare them and determine the level of city advancement in the implementation of urban logistics measures.

To overcome this problem, the EC initiated the concept of Sustainable Urban Logistics Plan (SULP), through the ENCLOSE [2] and SULPiTER projects aimed at a comprehensive approach to urban transport. Thanks to the ENCLOSE and SULPiTER projects, the document structure and approach to urban transport policy planning can be standardized, despite the differing urban conditions. The SULP methodology is based on the concept of SUMP implementation. To prepare SULP and choose urban logistics solutions that we choose for our city, you need to identify problems and set up a team. The appointed team must function not only at the administrative level, but also be based on partnership with stakeholders. The area to be covered (Functional Urban Area, FUA) should also be defined, as well as the initial conditions in the field of infrastructure, freight flows, traffic flow, the number of delivery companies, the number of recipients, as well as the attitude of stakeholders towards selected remedies (Fig. 2). 


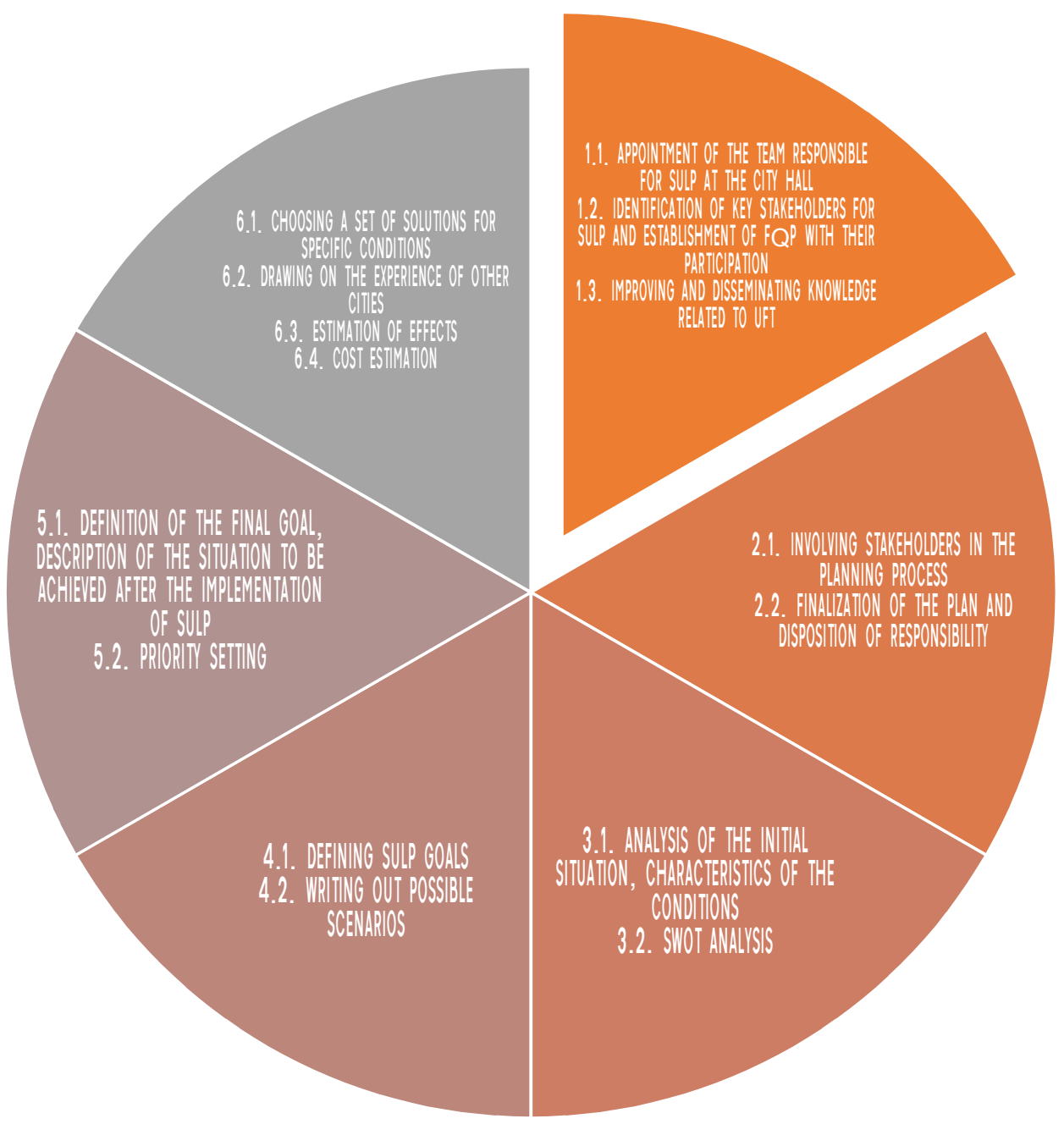

3. Stages of writing the Sustainable Urban Logistics Plan (SULP) Source: Personal research from [1]

SULP cannot be removed from any sphere of the city's life, which is why it must take into account not only the institutions concerned and the organization of work and the division of responsibilities, but also the political, business, infrastructure and technological dimension (Fig. 3). 


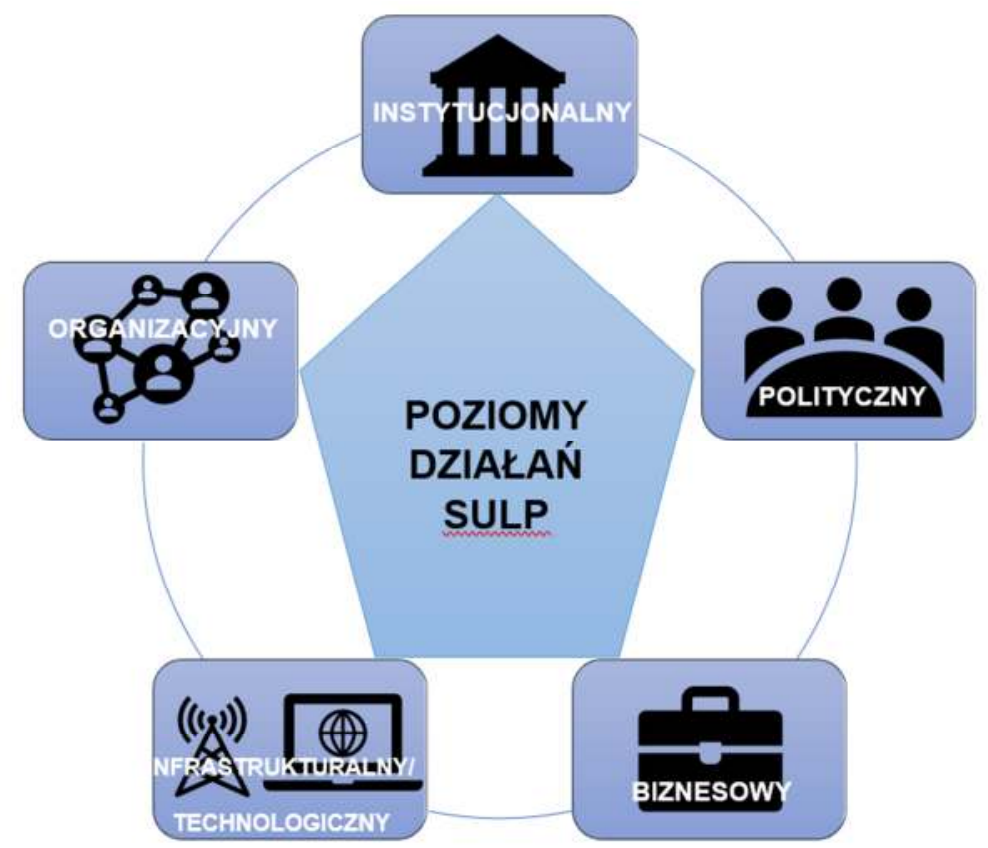

4. Impact levels of the Sustainable Urban Logistics Plan (SULP)

Source: Personal research from [1]

Areas of SULP's activities must be communicated to interested parties from the beginning of work on the document, using public relations tools (Fig. 4).

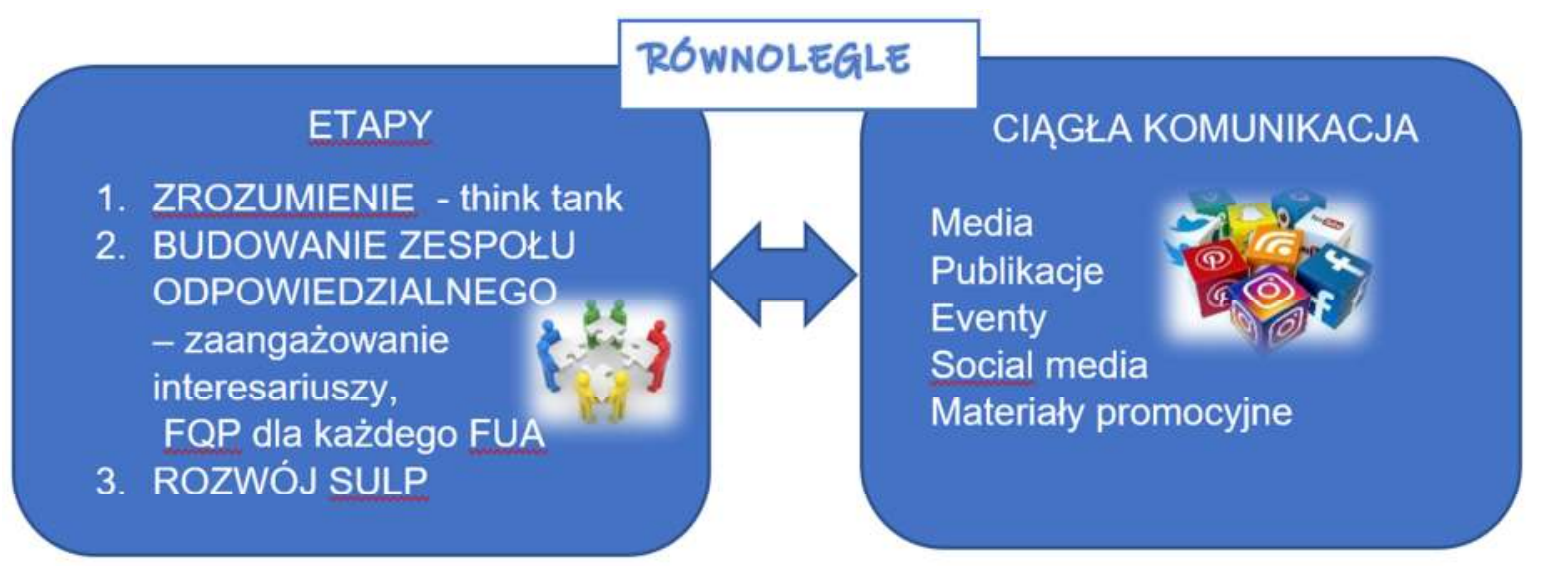

5. Marketing of a Sustainable Urban Logistics Plan from the beginning of work on it Soruce: Personal research

Under the SULPiTER project, dozens of European cities have been studied to identify an approach to building transport policy in the field of urban logistics. European cities included in the analysis were selected on the basis of their size, participation in projects and other relevant characteristics. The main idea was to examine a diverse sample. 129 cities were selected for analysis. The identified strategic documents of European cities were divided into five main categories:

- SUMPs that discuss the transport of goods in the city (38 cities),

- SUMPs that do not mention the transport of goods (7 cities),

- Mobility plans including freight (46 cities), 
- Logistic plans (6 cities),

- SULPs (9 cities).

SULP is the most comprehensive document devoted to logistics issues in urban areas.

The delivery of city freight is a very complex process, faced with numerous problems that must be solved in order to provide efficient services to customers. In order to deal with this complexity and problems of increasing traffic volume, energy consumption, pollutant emissions and congestion, various transport policy measures are adopted in cities around the world.

In the next phase of research, the sample of cities was reduced to 30 cities with accepted documents dealing with logistics issues. 158 selected logistic solutions were identified in selected cities. Out of 158, 58 best practices were selected and at the same time characterized by available data.

The selected solution was grouped into 10 groups that were used for detailed analysis. The main criteria for the final selection of measures was the application of the measure not only to the city center, but also at the city's FUA level.

The following measures have been identified:

- loading and unloading bays

- cargo bikes

- „clean” vehicles

- spatial planning taking into account supply

- dedicated road lanes for deliveries

- delivery and service plans

- mobile warehouses

- deliveries outside rush hour / night deliveries

- Logistics using the urban river

- urban consolidation center

Table 1 presents solutions for the distribution of goods in the city, which selected cities declare to be implemented in logistics plans. The table also includes harmonization of supply rules. 
Tab. 1. Logistical actions to be taken in selected cities declared in urban transport policy documents

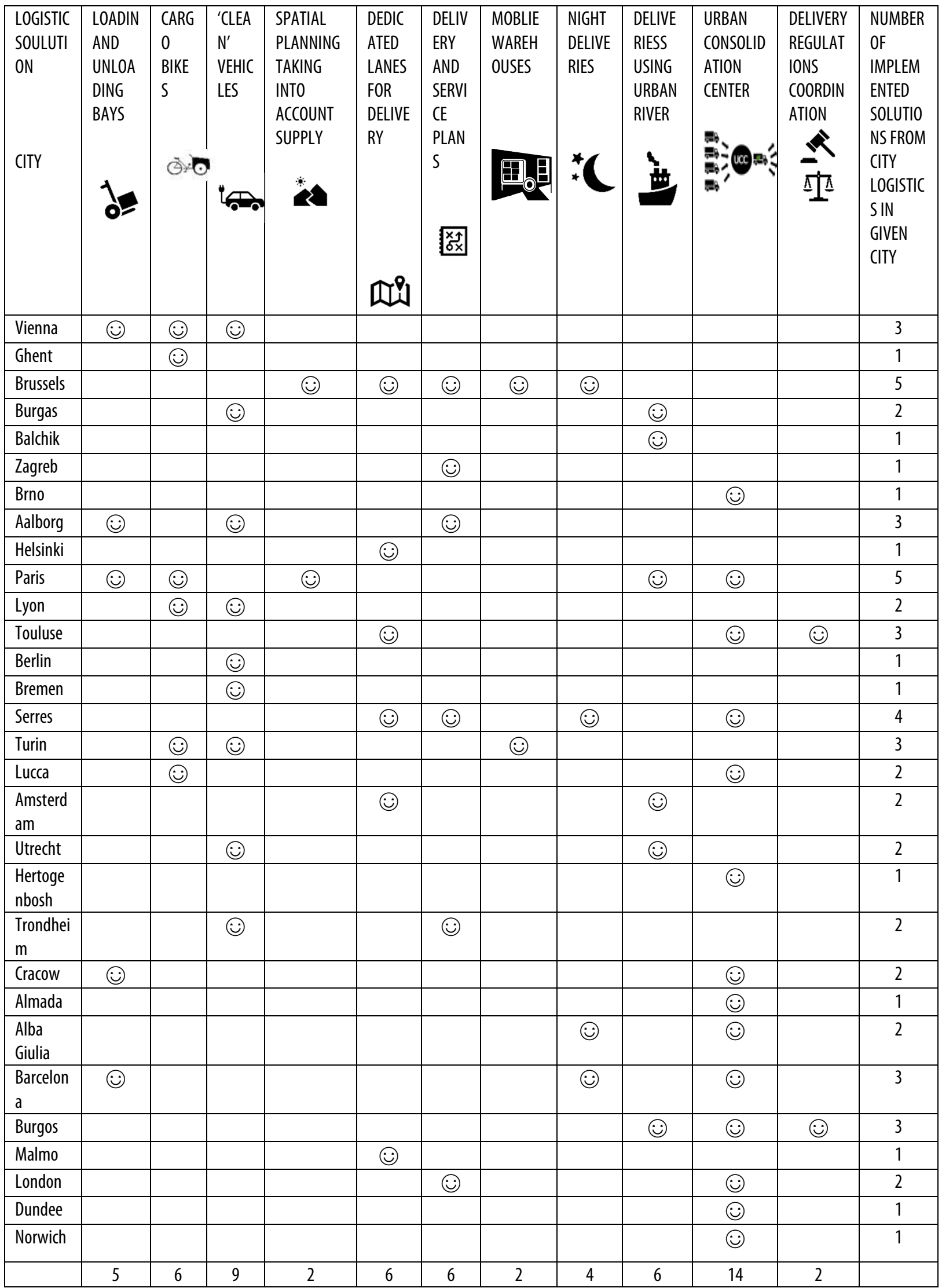

Source: Personal research from [3]. 
Brussels and Paris are the most advanced of all the cities analyzed - in strategic documents in the field of transport policy - these cities included 5 different solutions. Interestingly, 14 out of 30 plan to implement urban consolidation centers against which stakeholders are distant at the planning stage. Among the most popular means are also "clean" vehicles (planned in 9 cities) and cargo bikes (planned in 6 cities).

For a better understanding of the measures presented in Table 1, the actions were further compared qualitatively in terms of investment and operational costs as well as savings (Table 2).

Tab. 2. Investment expenditure vs. savings in relation to selected transport policy activities

\begin{tabular}{|c|c|c|c|c|c|c|c|c|c|c|c|}
\hline & $\begin{array}{l}\text { LOADIN } \\
\text { AND } \\
\text { UNLOAD } \\
\text { ING } \\
\text { BAYS } \\
\end{array}$ & $\begin{array}{l}\text { CARG } \\
0 \\
\text { BIKES } \\
\end{array}$ & $\begin{array}{l}\text { 'CLEA } \\
\text { N' } \\
\text { VEHIC } \\
\text { LES } \\
\end{array}$ & $\begin{array}{l}\text { SPATIAL } \\
\text { PLANNINGTA } \\
\text { KING INTO } \\
\text { ACCOUNT } \\
\text { SUPPLY }\end{array}$ & $\begin{array}{l}\text { DEDICA } \\
\text { TED } \\
\text { LANES } \\
\text { FOR } \\
\text { DELIVE } \\
\text { RY } \\
\\
\text { [W }\end{array}$ & $\begin{array}{l}\text { DELIVE } \\
\text { RY } \\
\text { AND } \\
\text { SERVIC } \\
\text { E } \\
\text { PLANS } \\
\\
\\
x_{x}\end{array}$ & $\begin{array}{l}\text { MOBILE } \\
\text { WAREHO } \\
\text { USES }\end{array}$ & $\begin{array}{l}\text { NIGHT } \\
\text { DELIVE } \\
\text { RIES }\end{array}$ & $\begin{array}{l}\text { DELIVERI } \\
\text { ESS } \\
\text { USING } \\
\text { URBAN } \\
\text { RIVER }\end{array}$ & $\begin{array}{l}\text { URBAN } \\
\text { CONSOLIDA } \\
\text { TION } \\
\text { CENTER } \\
\text { : }\end{array}$ & $\begin{array}{l}\text { DELIVERY } \\
\text { REGULATI } \\
\text { ONS } \\
\text { COORDINA } \\
\text { TION } \\
\text { II }\end{array}$ \\
\hline \multicolumn{12}{|c|}{$\begin{array}{l}\text { Investm } \\
\text { ents }\end{array}$} \\
\hline Low & & $\epsilon$ & & $\epsilon$ & $\epsilon$ & $\epsilon$ & $\epsilon$ & $\epsilon$ & & & $\epsilon$ \\
\hline $\begin{array}{l}\text { Mediu } \\
\text { m }\end{array}$ & $\epsilon$ & & & & & & & & $\epsilon$ & $\epsilon$ & \\
\hline High & & & $\epsilon$ & & & & & & & & \\
\hline \multicolumn{12}{|l|}{ Savings } \\
\hline Low & & & & & & & & & & & \\
\hline $\begin{array}{l}\text { Mediu } \\
\text { m }\end{array}$ & $\epsilon$ & $€$ & $\boldsymbol{\epsilon}$ & $\epsilon$ & & & $\epsilon$ & $\epsilon$ & $\epsilon$ & & $€$ \\
\hline high & & & & & $\bar{\epsilon}$ & $\epsilon$ & & & & $\epsilon$ & \\
\hline
\end{tabular}

Source: Personal research from [3].

Successful implementation of measures is in many cases related to the amount of investment needed to implement them. The lower the investment demand, the greater the possibility of implementing the measure. So-called soft measures (e.g. communication means, organizational measures) are often preferred by decision-makers over hard or investmentoriented measures (e.g. construction of a new street, new logistics terminal).

The greater the savings, the greater the possibility and need to implement the measures. Savings can be measured over time, costs, $\mathrm{CO} 2$ emissions and energy. Interestingly, most of the measures considered fall into the category of low investment needs. Based on their main purpose, the resources can be divided into groups: regulations, technologies, infrastructure, services, industry / economy, urban planning and energy (Table $3)$. 
Tab. 3. Division of urban logistics solutions by area of operation

\begin{tabular}{|c|c|c|c|c|c|c|c|c|c|c|c|}
\hline & $\begin{array}{l}\text { LOADIN } \\
\text { AND } \\
\text { UNLOAD } \\
\text { ING } \\
\text { BAYS }\end{array}$ & $\begin{array}{l}\text { CARG } \\
0 \\
\text { BIKES }\end{array}$ & $\begin{array}{l}\text { 'CLEA } \\
N^{\prime} \\
\text { VEHIC } \\
\text { LES }\end{array}$ & $\begin{array}{l}\text { SPATIAL } \\
\text { PLANIINGT } \\
\text { AKING INTO } \\
\text { ACCOUNT } \\
\text { SUPPLY }\end{array}$ & $\begin{array}{l}\text { DEDICA } \\
\text { TED } \\
\text { LANES } \\
\text { FOR } \\
\text { DELIVE }\end{array}$ & $\begin{array}{l}\text { DELIV } \\
\text { ERY } \\
\text { AND } \\
\text { SERVI } \\
\text { CE }\end{array}$ & $\begin{array}{l}\text { MOBILE } \\
\text { WAREHO } \\
\text { USES }\end{array}$ & $\begin{array}{l}\text { NIGHT } \\
\text { DELIVE } \\
\text { RIES }\end{array}$ & $\begin{array}{l}\text { DELIVERI } \\
\text { ESS } \\
\text { USING } \\
\text { URBAN } \\
\text { RIVER }\end{array}$ & $\begin{array}{l}\text { URBAN } \\
\text { CONSOLIDA } \\
\text { TION } \\
\text { CENTER }\end{array}$ & $\begin{array}{l}\text { DELIVERY } \\
\text { REGULATI } \\
\text { ONS } \\
\text { COORDINA } \\
\text { TION }\end{array}$ \\
\hline & of & & (1) & 2 & [थै] & 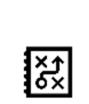 & & & & & \\
\hline $\begin{array}{l}\text { Regulatio } \\
\text { ns }\end{array}$ & $\downarrow$ & $\downarrow$ & 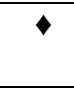 & & & & & & & $\downarrow$ & \\
\hline $\begin{array}{l}\text { Technolo } \\
\text { gies }\end{array}$ & & & $\bullet$ & & & & & & & & \\
\hline $\begin{array}{l}\text { Infrastruc } \\
\text { ture }\end{array}$ & $\downarrow$ & & $\bullet$ & $\bullet$ & $\bullet$ & & & & & $\downarrow$ & \\
\hline Services & & $\downarrow$ & & & & 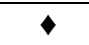 & $\bullet$ & $\downarrow$ & $\bullet$ & 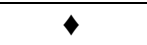 & $\bullet$ \\
\hline Industry & & & 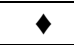 & & & $\downarrow$ & & & & & \\
\hline $\begin{array}{l}\text { Urban } \\
\text { planning }\end{array}$ & $\bullet$ & & & $\bullet$ & & & & & & & \\
\hline Energy & & & 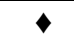 & & & & & & & & \\
\hline
\end{tabular}

Source: Personal research from [3].

Well-known European case studies show that well-chosen measures and / or their optimal combination can significantly reduce energy consumption and $\mathrm{CO} 2$ emissions. Individual measures can generate an average of around 20-30\% savings, while their optimal combination can result in around $60-70 \%$ savings.

Thanks to the optimal combination of resources, cities can contribute to the gradual implementation of the European Commission's goal of a CO2-free city.

Standardization of approaches in cities is necessary and recommended, which guarantees that SULP will be drawn up in accordance with the tool developed in the SULPiTER project. .

\section{Source materials:}

[1] Ambrosino, G, Developing and implementing a sustainable urban logistics plan. Guidelines,

[2] ENCLOSE Doc. Type/ No. / Title, Deliverable D5.2: “A Framework for the definition and implementation of Sustainable Urban Logistics Plans in historic small-/mid-size towns".

[3] Letnik, T., (2019), Urban freight transport policies and measures implemented in strategic documents of European cities - a review, European Review of Regional Logistics, nr 2, s. 12-15.

[4] Taniguchi, E., (2014), Concepts of city logistics for sustainable and liveable cities, $1^{\text {st }}$ International Conference Green Cities - Green Logistics for Greener Cities, Procedia Social and Behavioral Sciences 151, s. 310-317. 